$7-1-2012$

\title{
6-Hydroximino-4-Aza-A-Homo-Cholest-3-One and Related Analogue as A Potent Inducer of Apoptosis in Cancer Cells
}

\author{
Yanmin Huang \\ Guangxi Teachers Education University \\ Jianguo Cui \\ Guangxi Teachers Education University \\ Qiaoxia Zheng \\ Chinese Academy of Sciences \\ Chun Zeng \\ Cleveland State University \\ Quan Chen \\ Chinese Academy of Sciences
}

See next page for additional authors

Follow this and additional works at: https://engagedscholarship.csuohio.edu/scichem_facpub

Part of the Chemistry Commons

How does access to this work benefit you? Let us know!

\section{Recommended Citation}

Huang, Yanmin; Cui, Jianguo; Zheng, Qiaoxia; Zeng, Chun; Chen, Quan; and Zhou, Aimin,

"6-Hydroximino-4-Aza-A-Homo-Cholest-3-One and Related Analogue as A Potent Inducer of Apoptosis in Cancer Cells" (2012). Chemistry Faculty Publications. 372.

https://engagedscholarship.csuohio.edu/scichem_facpub/372

This Article is brought to you for free and open access by the Chemistry Department at EngagedScholarship@CSU. It has been accepted for inclusion in Chemistry Faculty Publications by an authorized administrator of EngagedScholarship@CSU. For more information, please contact library.es@csuohio.edu. 


\section{Authors}

Yanmin Huang, Jianguo Cui, Qiaoxia Zheng, Chun Zeng, Quan Chen, and Aimin Zhou 


\title{
6-Hydroximino-4-aza-A-homo-cholest-3-one and related analogue as a potent inducer of apoptosis in cancer cells
}

\author{
Yanmin Huang , Jianguo Cui , Qiaoxia Zheng , Chun Zeng , Quan Chen , Aimin Zhou
}

\section{Introduction}

The synthesis of some aza homosteroid compounds with unu sual and interesting structures has been reported recently [1 4 ]. These compounds exhibit valuable biological activities such as cytotoxicity and antibacteria. Study of aza homosteroids indicates that the presence of the characteristic group ( $\mathrm{NH} \mathrm{CO}$ ) in the aza homosteroid molecule has been demonstrated to be important in lowering toxicity and improving anti tumor activity of the com pounds in cancer treatment [5].

Recently we designed and synthesized several new steroidal lactams with the introduction of $\mathrm{N}$ atom on $\mathrm{A}$ or $\mathrm{D}$ ring. Our re sults have shown that these compounds displayed a distinct cyto toxicity against different cancer cell types [6,7]. In this study, we report that 6 hydroximino 4 aza A homo cholest 3 one (1) and 6 hydroxyl 4 aza A homo cholest 3 one (2), new steroidal lac tams were synthesized recently [8], exerted potent cytotoxic activ ity against several cancer cells including HT 29 (colorectal adenocarcinoma), GNE 2 (nasopharyngeal carcinoma), SPC A (lung carcinoma), Tu 686 (laryngocarcinoma) and PC 3 (prostate adeno carcinoma) cancer cells. Further investigation revealed that the compounds were able to induce cancer cell apoptosis and inhibited tumor growth in athymic mice.

\section{Materials and methods}

Drug preparations

The tested compounds (Fig. 1) were synthesized by previously described methods [8]. Stock solutions of the tested compounds were made immediately before use.

\section{Biological assays}

Cell culture and assay for cell viability

GNE 2 (nasopharyngeal carcinoma), SPC A (lung carcinoma) and $\mathrm{Tu} 686$ (laryngic carcinoma) cell lines were obtained by Guangxi Medical University (China); HT 29 (colorectal adenocarci noma) and PC 3 (prostate adenocarcinoma) cancer cells were ob tained by ATCC, Manassas, VA. Cells were grown in RPMI 1640 supplemented with $10 \%$ cosmic calf serum (Hyclone) and antibiot ics in a humidified atmosphere of $5 \% \mathrm{CO}_{2}$ at $37^{\circ} \mathrm{C}$. The viability of these cells was determined using the colorimetric CellTiter 96 aqueous Cell Proliferation Assay (MTT) according to the instruc tions provided by the manufacturer (Promega, Madison, WI). Briefly, cells ( $13 \times 10^{4}$ cells per well) were seeded in 96 wells plates. One day after seeding, the cells were treated with or with out different concentration of each compound and reincubated for $72 \mathrm{~h}$. After the cells were washed with sterile phosphate buffer sal ine (PBS), $190 \mu \mathrm{L}$ of RPMI 1640 and $10 \mu \mathrm{L}$ of the tetrazolium dye (MTT) $(5 \mathrm{mg} / \mathrm{mL})$ solution were added to each well, and the cells were incubated for an additional $4 \mathrm{~h}$. The medium was discarded; 


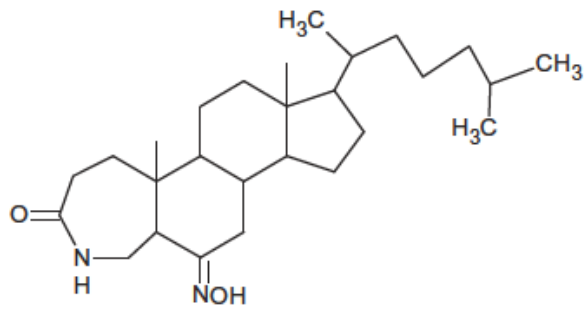

1

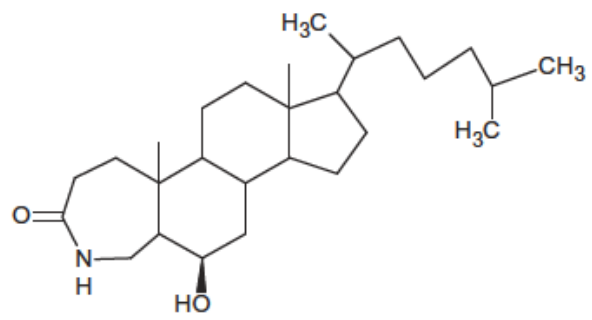

2

Fig. 1. Chemical structures of 6-hydroximino-4-aza-A-homo-cholest-3-one and 6-hydroxyl-4-aza-A-homo-cholest-3-one.

Table 1

In vitro anti-tumor activities ( $\mathrm{IC}_{50}$ in $\mu \mathrm{mol} / \mathrm{L}$ ) of the compounds.

\begin{tabular}{llllll}
\hline \multirow{2}{*}{ Compound } & \multicolumn{5}{l}{ Carcinoma cell lines } \\
\cline { 2 - 6 } & GNE 2 & SPC-A & Tu 686 & PC-3 & HT-29 \\
\hline 1 & 12.1 & 74.5 & 24.9 & 14.5 & 10.6 \\
2 & 15.8 & 35.3 & 31.2 & 18.3 & 15.5 \\
\hline
\end{tabular}

$200 \mu \mathrm{L}$ of DMSO was added to dissolve the purple formazan crys tals formed. The absorbance $(\mathrm{A})$ at $492 \mathrm{~nm}$ was measured using a Biocell ELISA analysis spectrometer.

Annexin $V$ assay

Annexin V assay was performed using an Annexin V FITC/propi dium iodine apoptosis detection kit (BD Biosciences, San Jose, CA). Briefly, cells treated with or without $10 \mu \mathrm{g} / \mathrm{mL}$ of compound 1 or 2 for 0,12 and $24 \mathrm{~h}$ or different concentrations of compound 1 or 2 for $12 \mathrm{~h}$ were scraped and centrifuged at $1000 \times \mathrm{g}$ for $10 \mathrm{~min}$ at $4{ }^{\circ} \mathrm{C}$, and washed with ice cold PBS, and then resuspended in $1 \times$ binding buffer provided by the manufacturer at a concentration of $1 \times 10^{6} / \mathrm{mL}$. FITC Annexin $\mathrm{V}(5 \mu \mathrm{L})$ and propidium iodide $(5 \mu \mathrm{L})$ were added to $100 \mu \mathrm{L}$ of the cell suspension and the cells were incubated at room temperature for $15 \mathrm{~min}$ in the dark. After incubation, $400 \mu \mathrm{L}$ of $1 \times$ binding buffer was added to the cell sus pension and the cells then were analyzed by two color cytometry using a FACScan ${ }^{\mathrm{M}}$ (Becton Dickinson, Franklin Lake, NJ).

\section{Immunofluorescent microscopy}

Cells were grown to $6070 \%$ confluence on a culture slide (BD Falcon, Bedford, MA). After treatment with $20 \mu \mathrm{g} / \mathrm{mL}$ of compound 1 for various times, the cells were rinsed twice with PBS, and fixed with freshly prepared $3.7 \%$ formaldehyde at $37{ }^{\circ} \mathrm{C}$ for $15 \mathrm{~min}$. The fixed cells were rinsed twice with PBS before incubated in $1 \mathrm{~mL}$ PBS containing $0.2 \%$ Triton X 100 and $1 \mu \mathrm{L}$ of $1 \mu \mathrm{g} / \mathrm{mL}$ DAPI for $10 \mathrm{~min}$ on ice. The cells were incubated with $5 \%$ goat serum for $30 \mathrm{~min}$ and then a monoclonal antibody to human cytochrome $\mathrm{c}$ (BD Biosciences, San Jose, CA) in PBS containing 1\% goat serum for $2 \mathrm{~h}$ at room temperature. After washing, the cells were incu bated with a secondary antibody conjugated with Cy3 (BD PharM ingen, San Diego, CA) for $1 \mathrm{~h}$ in dark. The cells were washed three times with PBS and covered with anti fade mounting medium. Cell images were captured with an LSM 510 Zeiss confocal microscope (Carl Zeiss, Inc. Thornwood, NY).

Western blot analysis

After treatment, cells were washed twice with ice cold phos phate buffered saline (PBS) and collected with a scraper. The cell pellet was resuspended in the extraction buffer containing $220 \mathrm{mM}$ mannitol, $68 \mathrm{mM}$ sucrose, $50 \mathrm{mM}$ PIPES KOH, pH 7.4, $50 \mathrm{mM} \mathrm{KCl}, 5 \mathrm{mM}$ EGTA, $2 \mathrm{mM} \mathrm{MgCl}$, $1 \mathrm{mM}$ dithiothreitol (DTT) and protease inhibitors. After $30 \mathrm{~min}$ incubation on ice, cells were homogenized with a glass dounce and a B pestle (40 strokes). Cell homogenates were spun at $14,000 \mathrm{~g}$ for $15 \mathrm{~min}$ and the cell extracts ( $100 \mu \mathrm{g}$ per sample) were fractionated on SDS $10 \%$ polyacrylamide gels and transferred to PVDF membranes (Millipore, Billerica, MA). The membranes were blocked with $5 \%$ nonfat milk in PBS containing $0.02 \%$ sodium azide and $0.2 \%(\mathrm{v} / \mathrm{v})$ Tween 20 , and incu bated with a monoclonal antibody to human cytochrome c (Santa Cruz, Biotechnology, Santa Cruz, CA) for $1 \mathrm{~h}$ at room temperature. The membranes were then washed with PBS containing $0.2 \%(\mathrm{v})$ v) Tween 20 and incubated with specific secondary antibodies con jugated with horseradish peroxidase (Cell Signaling, Billerica, MA) for $1 \mathrm{~h}$ at room temperature. After washing, these proteins were detected by a chemiluminescence method according to the manu facturer's specification (Pierce, Rockford, IL).

\section{Caspase activity}

Cells were treated with $20 \mu \mathrm{g} / \mathrm{mL}$ of compound 1 for 12 and $24 \mathrm{~h}$. The cells were trypsinized and washed twice with cold PBS. The washed cells $\left(1 \times 10^{6}\right.$ cells $)$ were incubated in $100 \mu \mathrm{L}$ of PBS containing $1 \mu \mathrm{L}$ FITC VAD FMK at room temperature in dark for $1525 \mathrm{~min}$. After washing once in PBS, the cells were re suspended in $400 \mu \mathrm{L}$ of PBS and analyzed by flow cytometry using a FACScan ${ }^{\mathrm{m}}$ (Becton Dickinson, Franklin Lake, NJ).

In vivo evaluation of therapeutic effectiveness

PC 3 cells $\left(1 \times 10^{6}\right)$ were injected subcutaneously into the ante rior flank of each mouse in six NCRNU M nude mice (Taconic, Hud son, NY) at 6 weeks old. Compound 1 was dissolved in DMSO to make a $10 \mathrm{mg} / \mathrm{mL}$ stock solution, which was diluted with PBS con taining $1 \%$ Tween 80 to reach a desired concentration for injection. Tumor volume was assessed by measuring length width height with a caliper. After tumors grew to a volume of $50 \mathrm{~mm}^{3}$, a half of the tumor bearing mice were intraperitoneally injected $10 \mathrm{mg} /$ $\mathrm{kg}$ body weight of compound $\mathbf{1}$ at the lower abdomen for five con secutive days. Rest of tumor bearing mice were injected with an equal amount of PBS containing $1 \%$ Tween 80 and the same volume of DMSO as used for compound $\mathbf{1}$ at the identical location. After termination of the experiment, tumors were excised, photo graphed and weighed. All animal studies were conducted in accor dance with the guidelines of the National Institute of Health for the Care and Use of Animals, and the protocol approved by the IACUC of Cleveland State University.

\section{Results and discussion}

\section{Antiproliferative activity of the compounds}

To evaluate the antiproliferative activity of the compound 1 and 2 , the $\mathrm{IC}_{50}$ values were determined in GNE 2, SPC A, Tu 686, HT 29 and PC 3 cancer cells by using a MTT assay according to the 
manufacturer's instructions. MTT [3 (4, 5 dimethylthiazol 2 yl) 2, 5 diphenyl tetrazolium bromide] is a compound that can be taken up by viable cells and reduced by a mitochondrial dehydrogenase forming a formazan product in living cells. The absorbance of the formazan product at $492 \mathrm{~nm}$ is in linear proportion to cell num bers. The results were summarized as $\mathrm{IC}_{50}$ values in $\mu \mathrm{mol} / \mathrm{L}$ in $\mathrm{Ta}$ ble 1. Apparently the compound $\mathbf{1}$ and $\mathbf{2}$ displayed a distinct antiproliferative function on these cancer cells.

\section{Compounds $\mathbf{1}$ and $\mathbf{2}$ induce apoptosis in cancer cells}

To determine the molecular mechanism by which the com pound 1 and $\mathbf{2}$ inhibit cancer cell proliferation, we further analyzed the cytotoxicity of the compound $\mathbf{1}$ and $\mathbf{2}$ in PC 3 cells. As shown in Fig. 2, both compound $\mathbf{1}$ and $\mathbf{2}$ induced PC 3 cell death could be clearly observed. To determine whether the decreased viability of PC 3 cells was due to the compound 1 or $\mathbf{2}$ induced apoptosis, the cells were treated with the compound $\mathbf{1}$ or $\mathbf{2}$, and subjected to Annexin $\mathrm{V}$ analysis. The translocation of membrane phospho lipid phosphatidylserine (PS) from the inner to the outer leaflet of the plasma membrane is an early event of cell apoptosis.
Annexin $\mathrm{V}$ is a $3536 \mathrm{kD} \mathrm{Ca}^{2+}$ dependent, phospholipid binding protein that has a high affinity for PS. Therefore, FITC conjugated Annexin V is commonly used to determine apoptotic cells at an early stage. As shown in Fig. 3, treatment with compound $\mathbf{1}$ and 2 resulted in $35.2 \%$ and $61.5 \% \mathrm{PI} /$ Annexin $\mathrm{V}$ double labeled apopto tic cells after $24 \mathrm{~h}$ incubation, suggesting both compounds are a potent apoptotic inducer in prostate cancer cells. The similar result was observed after PC 3 cells were treated with compound $\mathbf{1}$ and $\mathbf{2}$ in a dose dependent manner (Fig. 4). Treatment with $10 \mu \mathrm{g} / \mathrm{mL}$ of compound 1 for $24 \mathrm{~h}$ resulted in $42.2 \%$ PI/Annexin V double la beled apoptotic cells while compound 2 could produce $66.4 \%$ on the same condition, suggesting the compound $\mathbf{2}$ is more potent in induction of apoptosis in PC 3 cells.

To further evaluate compound $\mathbf{1}$ induced apoptosis in prostate cancer cells, we determined the activity of caspase 3 in the cells by a flow cytometry assay. Majority of the cells (81.28\%) after 24 h treatment with the compound 1 exerted caspase 3 activity (Fig. 5).

Cytochrome $\mathrm{c}$ is an electron transporting protein within the in ter membrane space of the mitochondria. It has been demon strated that cytochrome c plays an important role in apoptotic
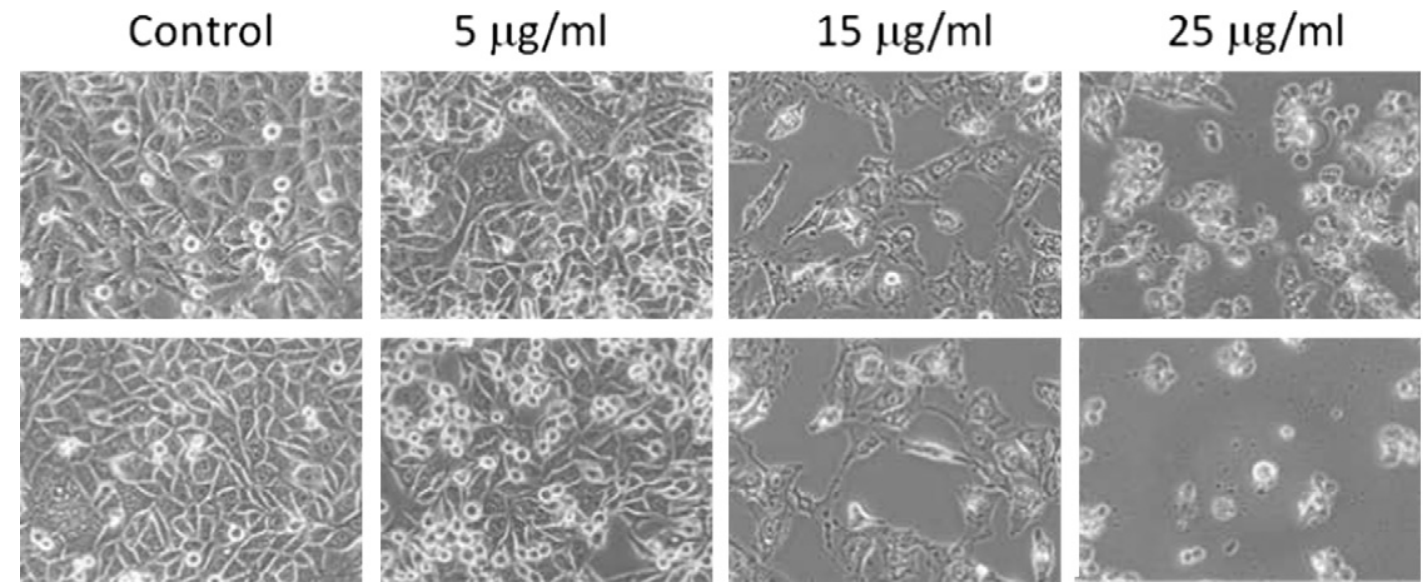

Comp1

Fig. 2. Photographs of the unstained cells were taken under Olympus model CKX31 at 100× magnification after treatment of PC-3 cells with various doses of compound $\mathbf{1}$ or $\mathbf{2}$ for $48 \mathrm{~h}$.
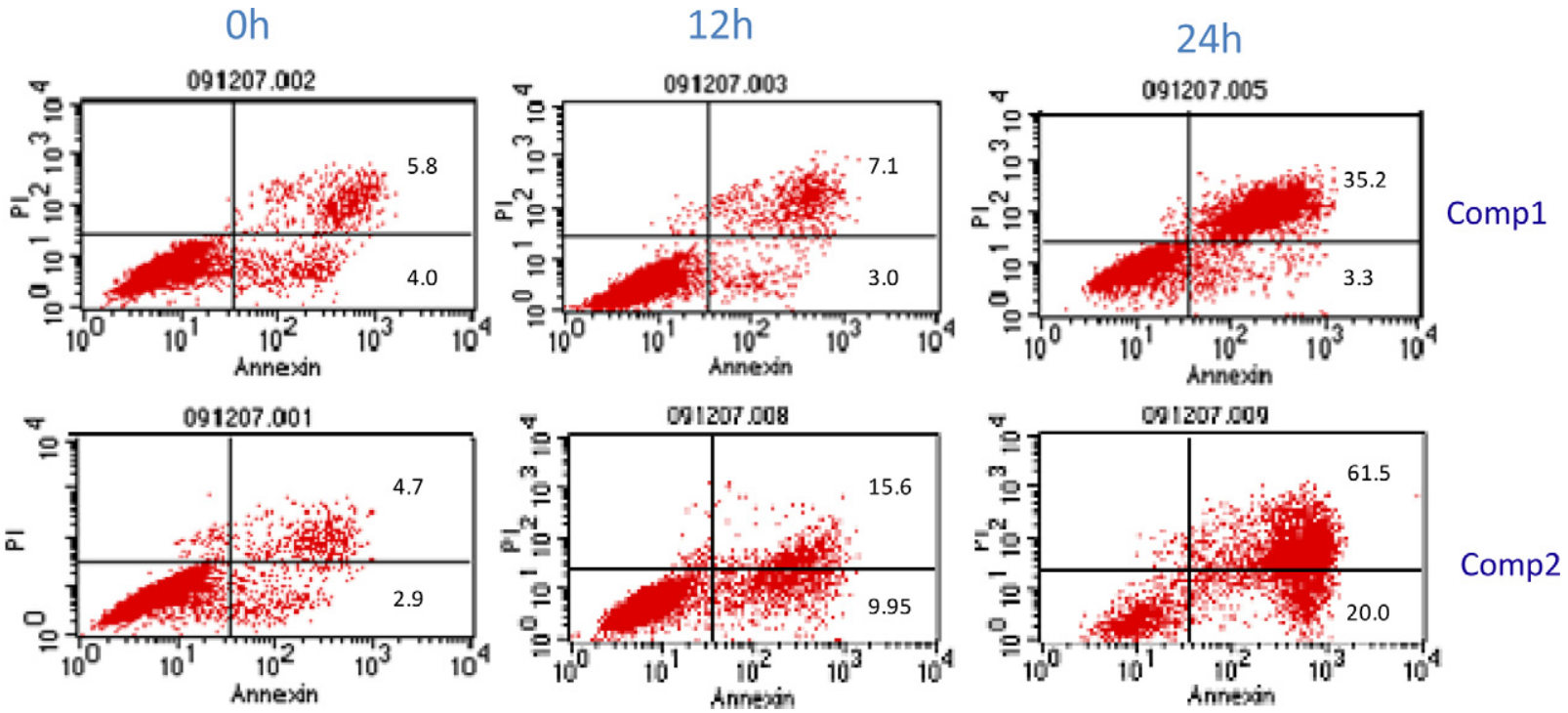

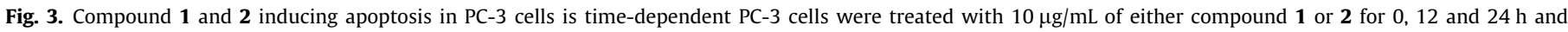
subjected to Annexin V and PI double staining. 
processes. In a healthy cell, cytochrome $\mathrm{c}$ is restricted within the mitochondrion. Upon apoptotic stimulation, cytochrome $\mathrm{c}$ is rapidly released into the cytoplasm to activate caspases. To deter mine the release of cytochrome c, PC 3 cells were treated with the

\section{Comp 1}

Con

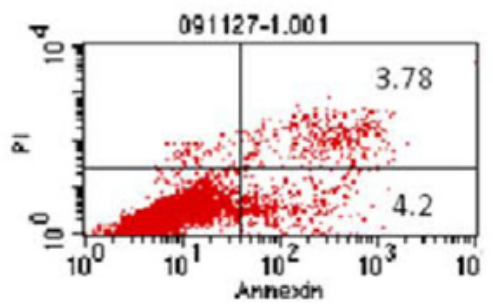

$10 \mu \mathrm{g} / \mathrm{ml}$

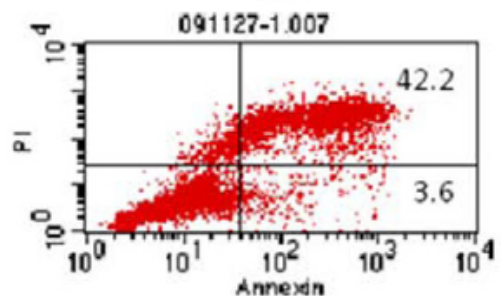

\section{Comp 2}
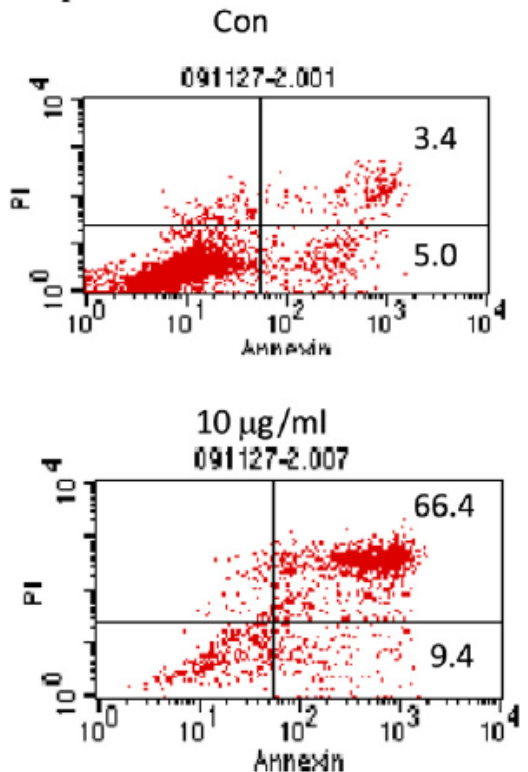

$2 \mu \mathrm{g} / \mathrm{ml}$

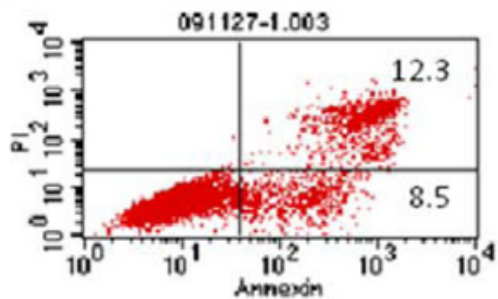

$15 \mu \mathrm{g} / \mathrm{ml}$
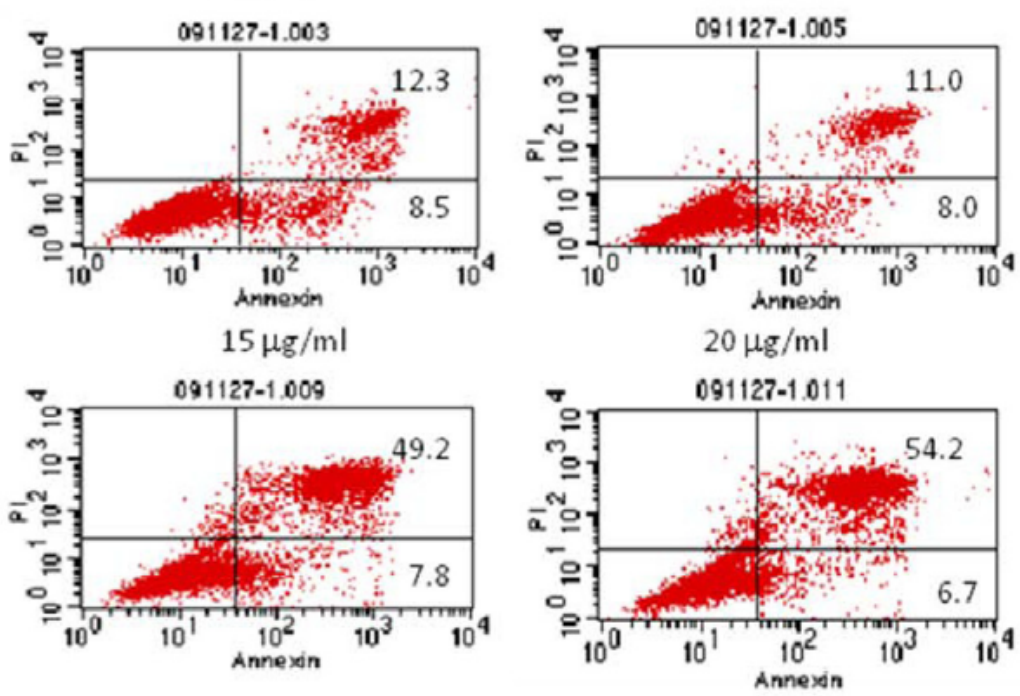

$20 \mu \mathrm{g} / \mathrm{ml}$

$5 \mu \mathrm{g} / \mathrm{ml}$
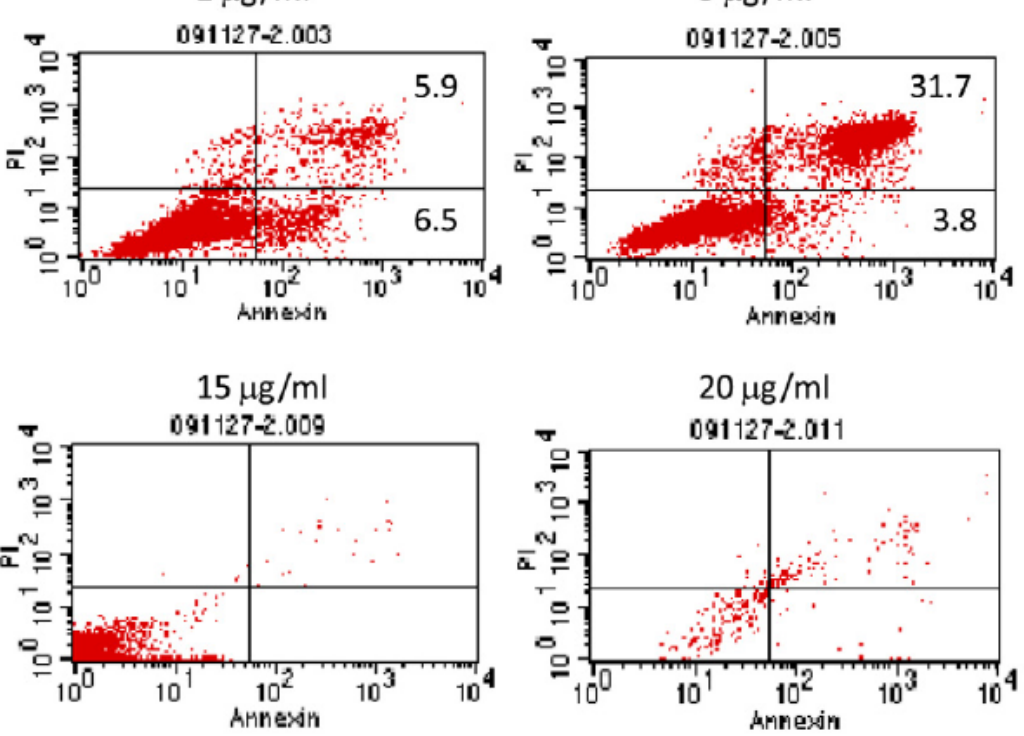

Fig. 4. Compound 1 and 2 inducing apoptosis in PC-3 cells is dose-dependent PC-3 cells were treated with different concentrations of compound 1 or 2 for 12 h and subjected to Annexin V and PI double staining.

Oh

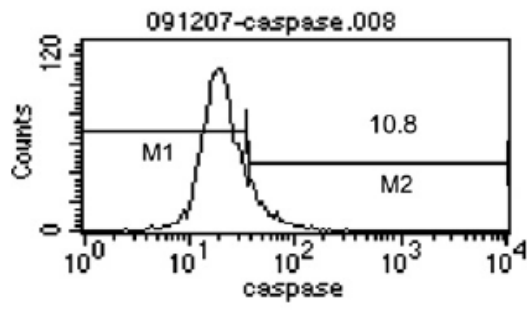

$12 \mathrm{~h}$

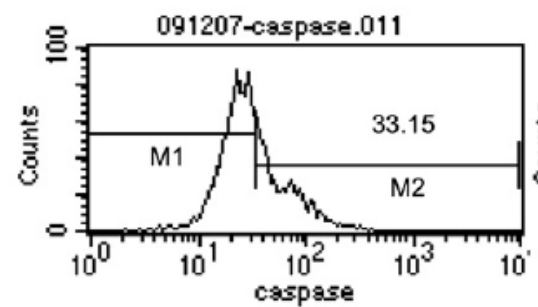

24h

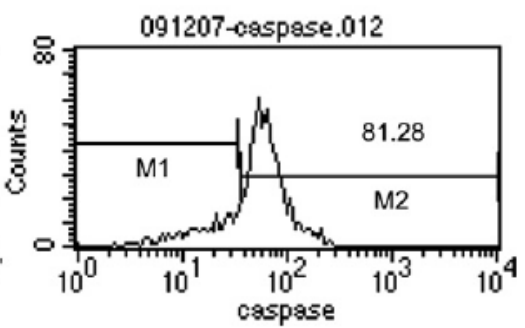

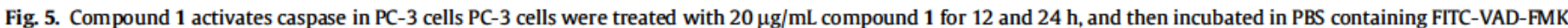

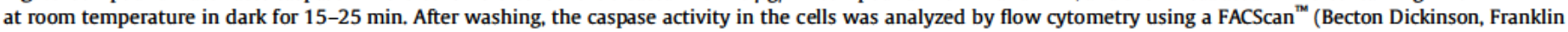
Lake, NJ). 
compound $\mathbf{1}$ for various times and presence of cytochrome $\mathrm{c}$ in cytoplasm was examined by Western blot analysis. Obviously cytosolic cytochrome c was not detectable in PC 3 cells without treatment. In contrast, cytosolic cytochrome c accumulated signif icantly after exposure to the compound 1 for $6 \mathrm{~h}$ (Fig. 6A). The en try of cytochrome c from mitochondria into the cytoplasm was confirmed by immunostaining with a monoclonal antibody against human cytochrome c (Fig. 6B). It is obvious that the longer the cells were incubated with compound $\mathbf{1}$, the more the cells were showing the release of cytochrome $C$ as arrows pointed out.

In mammalian cells, there are two major apoptosis pathways termed "extrinsic" and "intrinsic." The extrinsic pathway is activated by the binding of a "death" ligand to its receptor. Subse quently the adapter proteins FADD and caspase 8 are recruited to

A

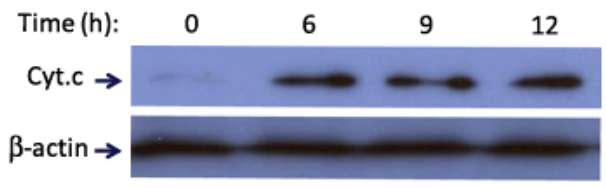

B

Cyto $C$
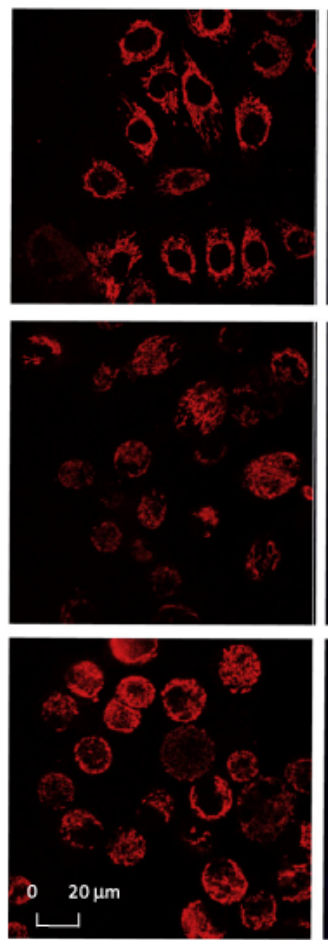

DAPI
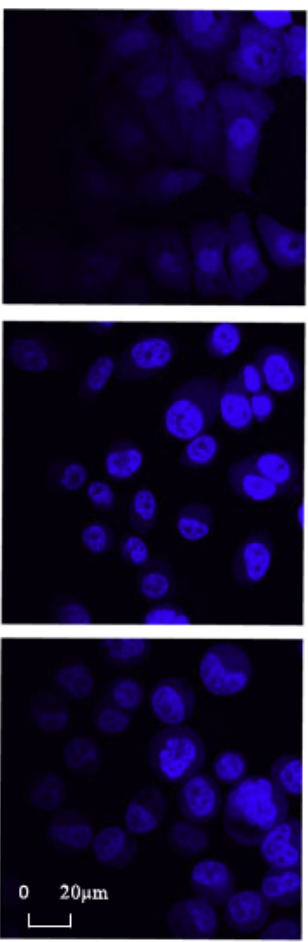

Merge
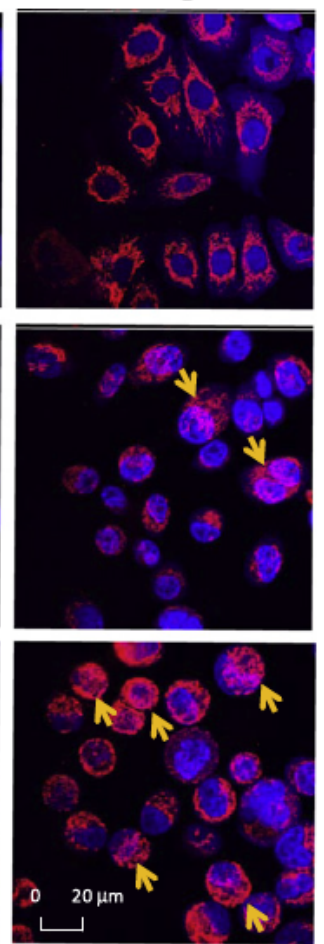

$\mathrm{Oh}$

$3 \mathrm{~h}$

$6 \mathrm{~h}$

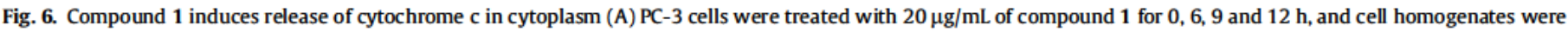

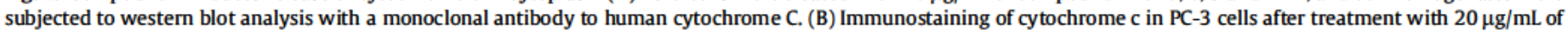
compound 1 for 0,3 and $6 \mathrm{~h}$. Arrows indicate the cells with a release of cytochrome c (magnification $20 \times$ ).

A

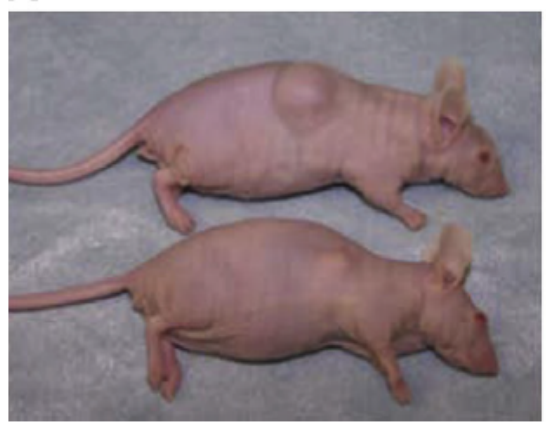

B

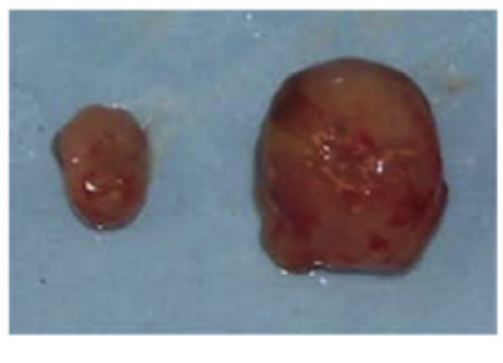

C

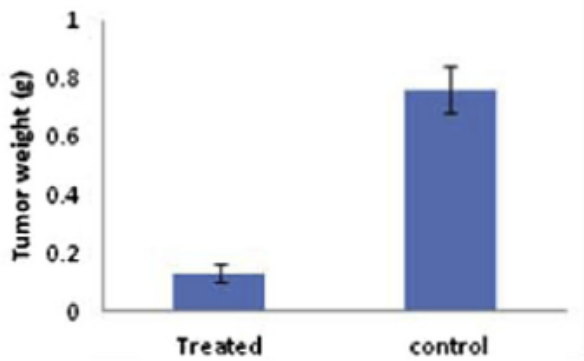

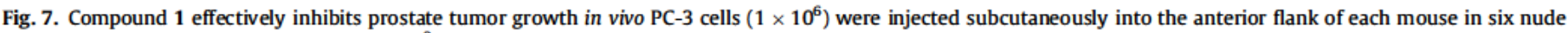

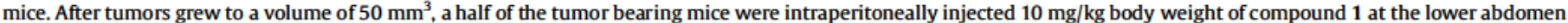

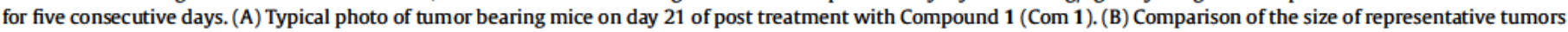
from mice treated with or without Com 1. (C) Tumors were weighed and represented as the mean \pm SD, $P<0.05$. 
the intracellular portion of the receptor, resulting in the activation of caspase 8 and 3 the effector enzymes in cell apoptosis. The intrinsic apoptotic pathway is characterized by permeabilization of the mitochondria in the injured cells, resulting in release of cyto chrome $\mathrm{c}$ into the cytoplasm. Cytochrome $\mathrm{c}$ then forms a multi protein complex known as the 'apoptosome' and initiates activa tion of the caspase cascade through caspase 9. Activated caspase 9 cleaves and activates caspase 3 , leading to apoptosis. Our results implicate that the compound $\mathbf{1}$ may induce apoptosis in PC 3 cells through activation of the intrinsic pathway although the exact molecular mechanism remains to be further elucidated.

\section{Inhibitory effect on the growth of xenografted tumors}

Clearly, compound $\mathbf{1}$ is able to induce apoptosis in prostate can cer cells. The potential to be a drug candidate is dependent of the effectiveness on tumor growth in vivo. To determine the therapeutic role of the compound $\mathbf{1}$ in tumor growth, PC 3 cells were implanted on the back near anterior limbs as described in the experimental section. The compound $\mathbf{1}$ dissolved in DMSO and diluted in PBS con taining $1 \%$ Tween 80 was intraperitoneally injected at the lower abdomen with $10 \mathrm{mg} / \mathrm{kg}$ body weight per day for five consecutive days. Obviously the compound was effective. The tumors on the mice treated with compound $\mathbf{1}$ were significantly growing slower. After termination of the experiment, the tumors were excised and weighed. As shown in Fig. 7A C, the average weight of tumors from mice treated with compound 1 was about 5.8 fold smaller than that in the control mice. The result suggests compound 1 may be a potent drug candidate for treating prostate cancer.

\section{Conclusion}

The antiproliferative activity of the new steroidal lactam 6 hydroximino 4 aza A homo cholest 3 one(1) and 6 hydroxyl 4 aza A homo cholest 3 one(2) against several cancer cell types was investigated. Our results revealed that the steroidal lactam compounds $\mathbf{1}$ and $\mathbf{2}$ displayed a distinct cytotoxicity against these cancer cells through effectively inducing cancer cell apoptosis by activation of the intrinsic pathway. Furthermore, the compound 1 inhibited tumor growth in an athymic mouse model, suggesting a potential for the compound to be a therapeutic drug candidate for prostate cancer treatment.

\section{Acknowledgment}

The authors acknowledge the financial support of the Natural Science Foundation of Guangxi Province, P.R. of China. (No: 2010GXNSFD013019).

\section{References}

[1] Natalija MK, Mira SB, Željko Ž, Mirjana DP, Zorica DJ, Vladimir DP. Synthesis of some steroidal oximes, lactams, thiolactams and their antitumor activities. Steroids 2007;72:406-14.

[2] Anna IK, Manolis A, Evagelia SA, Athanasios P, George NP, Sotiris SN. Rational design, synthesis, and in vivo evaluation of the antileukemic activity of six new alkylating steroidal esters. Bioorg \& Med Chem Lett 2008;16:5207-15.

[3] Dimitrios TPT, George DG, Catherine K, Athanasios P, Panayiotis K, Charalambos C. Lactandrate: a D-homo-aza-androsterone alkylator in the treatment of breast cancer. Breast Cancer Res Treat 2006;97:17-31.

[4] Mohamed EF, Gamal AE, Emad FE, Hanaa MR, Mohamed AT. Novel modified steroid derivatives of androstanolone as chemotherapeutic anti-cancer agents. Eur J Med Chem 2009;44:3936-46.

[5] Catsoulacos P, Catsoulacos D. Antitumor activity of homo-aza-steroidal esters of p-N, N-bis(2-chloroetheryl)amino phenoxy acetic acid. Anticancer Res 1993;13:1203-8.

[6] Huang YM, Chen SJ, Cui JG, Gan CF, Liu ZP, Wei YL, Song HC. Synthesis and cytotoxicity of A-homo-lactam derivatives of cholic acid and 7-deoxycholic acid. Steroids 2011;76:690-4.

[7] Huang YM, Cui JG, Zhong ZG, Gan CF, Zhang WY, Song HC. Synthesis and cytotoxicity of 17a-Aza-D-homo-androster-17-one derivatives. Bioorg Med Chem Lett 2011;21:3641-3.

[8] Huang Y, Cui J, Chen S, Gan C, Zhou A. Synthesis and antiproliferative activity of some steroidal lactams. Steroids 2011;76:1346-50. 